\title{
PROTEÇÃO DO NOME EMPRESARIAL, TÍTULO DE ESTABELECIMENTO E MARCA NÃO REGISTRADA EM FACE DA CONCORRÊNCIA DESLEAL.
}

\section{PROTECTION OF THE COMPANY NAME, TITLE OF ESTABLISHMENT AND TRADEMARK NOT RECORDED AGAINST UNFAIR COMPETITION.}

\author{
${ }^{1}$ Almir Garcia Fernandes
}

\section{RESUMO}

O nome empresarial, título de estabelecimento e marca não registrada são elementos incorpóreos sem identidade patrimonial que representam instrumento decisivo no sucesso empresarial, pois conquistam espaço de destaque na diferenciação de produtos e serviços, pela maior aproximação com consumidores e fornecedores. Este estudo tem por finalidade traçar um novo panorama de importância jurídica àqueles elementos incorpóreos, em especial às suas relações concorrenciais. Serão respondidos os questionamentos sobre os critérios para diferenciá-los e o seu conflito com marcas registradas. O método de pesquisa será o indutivo e os procedimentos metodológicos serão o estudo dogmático jurídico e sistemático.

Palavras-chave: Nome empresarial, Título de estabelecimento, Marcas não registradas

\begin{abstract}
The company name, title of establishment and unregistered trademark are intangible asset without identity representing decisive tool in business success as gain prominent space in the differentiation of products and services, by a closer relationship with customers and suppliers. This study aims to chart a new panorama of legal significance to those intangible elements, especially their competitive relations. The questions about the criteria to distinguish between them and their conflict with trademarks will be answered. The research method is the inductive and methodological procedures will be the legal and systematic dogmatic study.
\end{abstract}

Keywords: Company name, Title of establishment, Trademark not recorded

\footnotetext{
${ }^{1}$ Doutor em Direito Comercial pela Pontifícia Universidade Católica - PUC, São Paulo, (Brasil). Professor de Direito
} Empresarial no Centro Universitário do Planalto de Araxá - UNIRAXÁ, Minas Gerais. E-mail: almirgf@uol.com.br 


\section{INTRODUÇÃO}

A partir de 1980, com o desenvolvimento de meios tecnológicos que proporcionaram maior divulgação da atividade econômica empresarial, especialmente no ambiente virtual, a valorização de elementos incorpóreos explorados pelos empresários acabou apresentando uma nova dimensão econômica.

Atualmente destaca-se que não apenas os bens corpóreos, mas especialmente os bens incorpóreos representam uma parcela significativa do patrimônio empresarial, tais como direitos autorais, marcas e patentes.

Entretanto, também outros elementos despidos de identidade patrimonial e de igual natureza incorpórea vem se sobressaindo em importância para o empresário, tais como o nome empresarial, o título de estabelecimento e a marca não registrada. Mostrando-se igualmente decisivos para o sucesso da atividade empresária, pois conquistam um espaço de destaque na diferenciação dos produtos e serviços ofertados, de modo a gerar uma valorização dos negócios, criando assim uma identidade com consumidores e fornecedores.

Este estudo tem por finalidade traçar um novo panorama de importância jurídica àqueles elementos incorpóreos que não estão sujeitos à registro próprio, ou então cujo registro não lhes confere a condição de um bem específico, mas que mantém uma significativa importância para o empresário, pois mostram-se como instrumentos de diferenciação no universo da concorrência.

Buscar-se-á responder a alguns questionamentos relacionados à tutela dos elementos incorpóreos do estabelecimento empresarial, tais como: que critérios deveriam ser utilizados para diferenciais os nomes empresariais, títulos de estabelecimento e marcas não registrados? Seriam essas critérios os mesmos utilizados na proteção do universo de marcas registradas? Há possibilidade jurídica de proteção à marcas não registradas? Como compatibilizar a proteção jurídica de nomes empresariais e títulos de estabelecimento quando os mesmos encontrarem elementos gramaticais idênticos à marcas registradas?

Pretende-se traçar um panorama atual da tutela que se confere ao nome empresarial, ao título de estabelecimento e marcas não registradas, aqui indicadas como elementos incorpóreos do estabelecimento empresarial, apresentando suas definições e apontando diversos aspectos polêmicos relacionados às normas de proteção à concorrência previstas na Lei 9.279/96.

Será utilizado como método de pesquisa o indutivo, a saber, aquele destinado a verificar constatações particulares, e possibilitar, que se produzam generalizações sobre o tema. 
Os procedimentos metodológicos a serem utilizados serão o estudo dogmático jurídico, visto a impossibilidade de um estudo profundo sem que se recorra à lei, à doutrina ou à jurisprudência neste sentido; e o estudo sistemático, visando interpretar as regras específicas da pesquisa em harmonia com todo o sistema jurídico.

\section{1 - O ESTABELECIMENTO EMPRESARIAL}

Compreende-se por estabelecimento empresarial o complexo de bens organizados que tem por finalidade o exercício da empresa. "Trata-se de elemento indissociável à empresa. Não existe como dar início à exploração de qualquer atividade empresarial, sem a organização de um estabelecimento." (COELHO, 2012, p. 157).

Esse complexo de bens possui natureza jurídica de universalidade de fato, formado por coisas corpóreas, incorpóreas, direitos e fornecimentos ${ }^{1}$, que se destinam ou que contribuam ao exercício da atividade empresarial, com exceção dos bens particulares dos sócios ou àqueles que não estiverem voltados para essa finalidade. Possuem "em comum o fato de se encontrarem interligados para a prática do comércio.” (CORDEIRO, 2012, p. 329).

De todo esse conjunto de bens que compõe o estabelecimento empresarial, os incorpóreos ganharam significativa importância a partir do final do século XX, tornando-se indispensáveis às empresas no universo competitivo. Dentre eles destacam-se aqueles que possuem natureza jurídica de coisas (res) e outros despidos dessa condição, caracterizado como simples direitos, todos de reconhecida importância econômica, tais como: ponto comercial, bens da propriedade industrial, direitos autorais, os softwares, elementos de propaganda, título de estabelecimento, nome empresarial. Bem como os atributos da empresa: aviamento e clientela.

Sua valorização acompanhou o reconhecimento dos bens da Propriedade Industrial, pois contribuem "direta ou indiretamente para o desenvolvimento econômico" (BUENO, 2006, p. 32), bem como pela apropriação da tecnologia, como destaca Paula FORGIONI (2009, p.171/172):

A partir dos anos 80, aflorou a chamada Economia da Informação, consolidando ambiente no qual a força competitiva das empresas depende de sua capacidade de gerar, processar e aplicar

\footnotetext{
${ }^{1}$ VIVANTE, Cesare, destacou os seguintes bens do estabelecimento empresarial: As coisas corpóreas, como os produtos da indústria, as máquinas etc. Os direitos, e entre eles principalmente o uso exclusivo de firmas, das marcas de fábrica, dos privilégios industriais, das denominações comerciais, os direitos do autor; Os fornecimentos, isto é, a esperança de lucros futuros, fundada nos dois grupos de coisas e de direitos precedentes e especialmente sobre o sortimento das mercadorias, sobre o nome, sobre a denominação, sobre a situação local, que serve o reclamo aos antigos e aos novos clientes. (2007, p. 147).
} 
informações. Essa mudança no ambiente institucional mostra-se tão marcada que muitos passam a identificar o ente produtivo com a organização de quatro fatores de produção: capital, trabalho, recursos naturais e tecnologia.

A importância das inovações tecnológicas e dos elementos incorpóreos no universo empresarial refletiu-se inclusive nas políticas públicas que passaram a ser implementadas no Brasil a partir dos anos 90, especialmente após a promulgação da Lei da Propriedade Industrial (Lei 9.279/96). Isso ficou evidente na análise de dados estatísticos que comprovaram um aumento de $277 \%$ no número de solicitações de patentes apresentadas ao INPI desde a promulgação da Lei 9.279/96 até o ano de $2012^{2}$.

A importância não só da tecnologia, bem como das marcas que distinguem os produtos, destacou esses bens incorpóreos dos demais que compõe o estabelecimento empresarial $^{3}$, aproximando-os do universo da Concorrência, uma vez que eles são importantes elementos para atrair a clientela. Lembrando que "para a existência da concorrência, seja ela leal ou desleal será sempre necessária a presença da clientela, uma vez que esta é quem efetivamente faz o sucesso do negócio" (ALMEIDA, 2004, p. 140).

Entretanto, ao contrário dos bens da propriedade industrial, que apresentam uma tutela específica e bem definida, os elementos incorpóreos do estabelecimento empresarial, tais como o nome empresarial, o título de estabelecimento e a marca não registrada ainda são objeto de dúvidas quanto à forma mais adequada à sua proteção.

A necessidade do empresário de se destacar perante seus concorrentes e o amplo desenvolvimento de meios de comunicação e de propaganda acabaram por incrementar hipóteses de atuação abusiva e aproveitamento de sinais e nomes utilizados pelos empresários.

Enquanto a exploração de bens da propriedade industrial, tais como as marcas e patentes, são garantidas por registros próprios, o que permite ao empresário excluir àqueles não autorizados ao seu uso, no caso do nome empresarial, do título de estabelecimento e das marcas não registradas, não há a mesma clareza em sua exploração econômica, havendo então a

\footnotetext{
${ }^{2}$ Segundo dados estatísticos fornecidos pela OMPI. O Brasil em 1996 teve um total de 8.057 pedidos de patente, enquanto que em 2012 esse número passou para 30.435 pedidos, o que mostra evidente evolução. Disponível em http://ipstats. wipo.int/ipstatv2/ipsStakeBarchart. Acesso em 14 de julho de 2015.

${ }^{3}$ PONTES DE MIRANDA, já enfatizava essa relação entre os bens objeto da propriedade industrial e o patrimônio empresarial: Se, quanto às patentes, podem elas estar ou não estar incluídas no fundo de empresa, tronando-se, ou não, partes dele, o que depende, apenas, de ligação negocial ou de aquisição inicial pela empresa, o mesmo não se dá no que concerne aos sinais distintivos. O sinal distintivo é pertença do fundo de empresa ou de gênero de comércio ou indústria, razão por que só se lhe transfere a propriedade transferindo-se a do fundo de empresa ou do gênero de comércio ou indústria. Tão intensa é essa destinação do sinal distintivo que, ainda antes de se instalar o estabelecimento ou se iniciar a exploração do gênero de empresa, ela se reflete na existência de eficácia do direito real. (2013, p. 412).
} 
necessidade de estudo separado dos três elementos destacados nessa pesquisa, o que se faz a seguir.

\section{2 - NOME EMPRESARIAL}

O nome empresarial compreende a expressão de individualização do empresário, identificado no contrato ou estatuto social, devidamente arquivado perante a Junta Comercial do Estado onde são exercidas as atividades econômicas.

Apresenta função parecida com o nome civil das pessoas naturais, sendo um instrumento para a individualização do empresário ${ }^{4}$, dentre outros, com elementos que servem para demonstrar a existência de sócios, limitação de responsabilidades e a atividade econômica explorada. "O que se chama de nome empresarial nada mais é do que a ideia e a prática do nome aplicados à empresa e às práticas mercantis” (MAMEDE, 2004, p. 101).

Existem duas espécies distintas de nome empresarial: a firma e a denominação. Firma é o nome empresarial formado pelo nome completo do titular da empresa individual ou pelos sobrenomes dos sócios de sociedade empresária, acompanhados de expressão indicativa do tipo societário. Denominação é a espécie de nome empresarial formada "pela utilização de expressões de fantasia ou o nome de alguém que tenha concorrido para o êxito da empresa, sócio ou não, acrescido de expressões indicativas do tipo societário" (GONÇALVES NETO, 2012, p 665).

Os nomes empresariais subordinam-se aos princípios da novidade e da veracidade. $\mathrm{O}$ primeiro garante o uso exclusivo do nome àqueles que o registraram, não podendo ser "idêntico, nem semelhante a outros já existentes no mesmo âmbito de proteção” (TOMAZETTE, 2008, p. 130). O segundo impede o empresário de utilizar na formação de seu nome ideia falsa sobre suas atividades ou seus sócios, impedindo que terceiros venham a ser induzidos a erro em relações jurídicas.

Tanto a denominação quanto a firma tem a função de designar o empresário, distinguindo-o dos demais, servindo como um instrumento de boa reputação ou de crédito para os clientes e fornecedores (c.f. CARVALHO DE MENDONÇA, 2008, p. 14)

Essa necessidade de diferenciação dos nomes empresariais destaca-se no parágrafo único do art. 1.163 do Código Civil, que exige do empresário a inclusão de elemento distintivo

\footnotetext{
${ }^{4}$ Nesse sentido ALMEIDA, M. E. M de: "Na propriedade industrial impera a posição Objetivista, onde o que se pretende é a proteção do nome em razão da individualidade do comerciante ou do complexo do estabelecimento - fundo de comércio. Propriedade Industrial frente à concorrência desleal (2000, p. 119).
} 
para evitar a confusão com outros e, consequentemente, a concorrência desleal, pois o inciso V do art. 195 da Lei 9279/96 declara ser crime o uso indevido do nome empresarial ou a exposição ou venda de produtos com essa referência.

Entretanto, resta a dúvida de que critérios deveriam ser utilizados para diferenciais os nomes empresariais? Seriam esses critérios os mesmos utilizados na proteção do universo marcário?

As respostas a esses questionamentos começa pela constatação de que os critérios utilizados para diferenciação de bens da propriedade industrial (especialidade, homofonia) nem sempre podem ser aplicados da mesma forma aos nomes empresariais, sendo muitas vezes incompatíveis.

Nesse sentido, o DREI (Departamento de Registro Empresarial e Integração), no artigo $8^{\circ}$ da instrução normativa 15 do de 05 de dezembro de 2013, definiu critérios para analisar eventuais distinções ou semelhanças entre os nomes empresariais pelo:

I - entre firmas, consideram-se os nomes por inteiro, havendo identidade se homógrafos e semelhança se homófonos;

II - entre denominações:

a) consideram-se os nomes por inteiro, quando compostos por expressões comuns, de fantasia, de uso generalizado ou vulgar, ocorrendo identidade se homógrafos e semelhança se homófonos;

b) quando contiverem expressões de fantasia incomuns, serão elas analisadas isoladamente, ocorrendo identidade se homógrafas e semelhança se homófonas.

Eventual confusão com a proteção marcaria pode ser explicada pelo fato de que a tutela outorgada ao nome empresarial já foi regulada "por certo tempo, pelas leis de propriedade industrial, pois poderiam ser requeridos dentro da generalidade das marcas" (COPETTI, 2010, p. 102). Há de se considerar, inclusive que o nome empresarial também foi objeto de tutela pela Convenção da União de Paris, cujo artigo $8^{\circ 5}$ determinou: “O nome comercial será protegido em todos os países da União sem obrigações de depósito ou de registro, quer faça ou não parte de uma marca de fábrica ou de comércio."

Essa proteção foi necessária e anda se justifica atualmente, pois o nome empresarial importa na própria identidade da empresa, revestindo-se de aspecto personalíssimo, não sendo permitida a sua alienação isolada, tal como indicado no art. 1164 do Código Civil Brasileiro (c.f. DINIZ, 2010, p. 798).

\footnotetext{
${ }^{5}$ Devidamente revisto pela Convenção de Estocolmo (Decreto n. 75.572 - de 8 de abril de 1975),
} 
Entretanto, a abrangência territorial promulgada pelo mencionado artigo $8^{\circ}$ da C.U.P. foi restrita ao âmbito do órgão de registro ao qual o nome empresarial está inscrito, tal como indica o art. 1163 do Código Civil, bem como o $§ 1^{\circ}$ do artigo 63 do Decreto 1800/96. Assim, a proteção ao nome empresarial circunscreve-se à unidade federativa de jurisdição da Junta Comercial que procedeu ao arquivamento do contrato ou estatuto social, bem como das declarações de Empresário Individual ou Empresa Individual de Responsabilidade Limitada. Caso o empresário pretenda estender essa proteção, deverá fazer requerimento às Juntas Comerciais de outros Estados da Federação.

Se algum elemento gramatical do nome empresarial, tal como o seu radical mais forte ${ }^{6}$, encontrar identidade com marca devidamente registrada junto ao INPI, prevalecerá a proteção territorial da marca em detrimento do nome empresarial, lembrando que a marca é tutelada em todo o território nacional. Portanto, quando o nome empresarial for gramaticalmente idêntico a uma marca registrada, não será permitido a outro empresário registrar nome empresarial idêntico, homófono ou com o mesmo radical, mesmo que isso venha a ocorrer em outra unidade da federação, sob a circunscrição de outra Junta Comercial, pois a proteção conferida pelo I.N.P.I. se estende a todo o território nacional.

Entretanto, não se pode deixar de ressaltar que a tutela legislativa conferida às marcas lhes subordina ao princípio da especialidade ${ }^{7}$, portanto, essa identidade entre nome empresarial e marca não será suficiente para garantir a proteção nacional se os empresários postulantes ao nome empresarial não estiverem explorando atividades econômicas incluídas na mesma classe de produtos ou serviços. Esse é o atual posicionamento do Superior Tribunal de Justiça, pelo qual se destaca um pequeno trecho da ementa do REsp 1357912 - SP:

Conforme recente jurisprudência da Terceira Turma deste Tribunal, havendo colidência entre marca e nome comercial, a questão não deve ser analisada apenas sob a ótica da anterioridade do registro, mas também pelos princípios da territorialidade e da especialidade. ${ }^{8}$

\footnotetext{
${ }^{6}$ Evidencia-se que a identidade gramatical entre a marca e o nome empresarial ocorre principalmente pela utilização da expressão radical mais forte da nome empresarial, o qual quando registrado como marca junto ao I.N.P.I passa a ser reconhecido tecnicamente como mot vedette. Veja-se o caso da empresa Bunge Alimentos S.A., cuja marca registra é apenas a palavra Bunge, ou então a empresa Bradesco S.A., cuja marca é apenas Bradesco, dentre outras. Nesses casos o mot vedette seriam as palavras Bung e Bradesco.

${ }^{7} \mathrm{O}$ princípio da especialidade permite a exploração das marcas de "maneira mais restrita possível, dentro das finalidades de assinalação da marca: apenas nos limites do mercado ao qual a marca é dedicada" (BARBOSA, 2013, p. 401).

${ }^{8}$ Disponível em: http://www.stj.jus.br/SCON/jurisprudencia/toc.jsp.
} 
Nesses casos a proteção do nome empresarial continua restrita à abrangência territorial que lhe é peculiar em virtude do registro na Junta Comercial, mantendo-se, entretanto, a proteção ao mot vedette registrado como marca em todo território nacional, em respeito ao princípio da especialidade. Importante lembrar que "o nome empresarial (firma ou razão social), o título de estabelecimento e a marca, embora possuam semelhanças, não se confundem entre si” (COPETTI, 2010, p. 103).

Por outro lado, não é possível aplicar apenas a regra do princípio da anterioridade se houver conflito entre o mot vedette do nome empresarial e a marca registrada quando seus titulares forem empresários distintos.

Nessas situações o posicionamento jurisprudencial predominante é de que a marca terá prioridade de proteção, mesmo que seu radical mais forte tenha sido registrado em momento posterior ao registro do nome empresarial ${ }^{9}$, desde que não sejam suscetíveis de causar confusão ao mercado e que o empresário não tenha estendido sua proteção de registro na Junta Comercial para todas as demais unidades da federação, tal como previsto no artigo 61 do Decreto 1.800 de 30 de janeiro de 1996.

Outra questão polêmica envolvendo o nome empresarial e a possibilidade de se estabelecer relações de concorrência desleal por sua utilização indevida está na hipótese de utilização de patronímico familiar no nome empresarial.

Nesse caso, salvo os nomes de pessoas famosas, ou apelidos consagrados, em que a utilização depende de autorização expressa de seus titulares, tem-se que as expressões derivadas de nomes de família causam impedimentos exclusivamente no uso empresarial, ou seja, os patronímicos não geram direito de utilização exclusiva fora das relações empresariais, pois que também são considerados direitos da personalidade de outros titulares no universo civil.

Os patronímicos familiares podem ser utilizados como elementos gramaticais ou radicais de marcas ou nomes empresariais, entretanto, àqueles que se utilizam deles não possuem garantida a exclusividade sobre o patronímico individualmente. A proteção no

\footnotetext{
${ }^{9}$ Nesse sentido, trecho do julgamento do Resp. $\mathrm{N}^{\circ}$ 1.204.488 - RS (2010/0142667-8):A proteção de denominações ou de nomes civis encontra-se prevista como tópico da legislação marcária (art. 65, V e XII, da Lei no 5.772/71), pelo que o exame de eventual colidência não pode ser dirimido exclusivamente com base no critério da anterioridade, subordinando-se, ao revés, em atenção à interpretação sistemática, aos preceitos legais condizentes à reprodução ou imitação de marcas, é dizer, aos arts. 59 e 65, XVII, da Lei no 5.772/71, consagradores do princípio da especificidade. Precedentes. 4. Disso decorre que, para a aferição de eventual colidência entre denominação e marca, não se pode restringir-se à análise do critério da anterioridade, mas deve também se levar em consideração os dois princípios básicos do direito marcário nacional: (i) o princípio da territorialidade, ligado ao âmbito geográfico de proteção; e (ii) o princípio da especificidade, segundo o qual a proteção da marca, salvo quando declarada pelo INPI de "alto renome" (ou "notória", segundo o art. 67 da Lei 5.772/71), está diretamente vinculada ao tipo de produto ou serviço, como corolário da necessidade de se evitar erro, dúvida ou confusão entre os usuários. Disponível em: http://www.stj.jus.br/SCON/jurisprudencia/toc.jsp. Acesso em 30 de julho de 2015.
} 
universo empresarial estará adstrita à identidade gramatical, bem como ao critério da anterioridade, ou seja, aquele homônimo que primeiro promover o registro terá preferência na sua utilização no universo empresarial.

Nesse sentido, O STJ na decisão do REsp 406.763/SP firmou o entendimento de que a utilização de nomes familiares no universo empresarial dependem do critério de anterioridade do registro, pelo qual destaca-se o comentário de Mamede (2004 p, 117):

O que se examina é, apenas, se a circunstância de se tratar de patronímico dos sócios exclui a proteção. Entendo que não. Não há distinção na Convenção de Paris sobre tal aspecto. O que deve prevalecer é a anterioridade do registro. Comprovado que o da autora é anterior, não pode a ré dele fazer uso, pouco importando que seja o patronímico de seus sócios.

A tutela do patronímico relacionada apenas as atividade empresariais está no fato de que o nome empresarial será reconhecido economicamente tal como uma marca, entretanto, esses dois institutos jurídicos não podem se confundir, pois possuem naturezas jurídicas distintas. Enquanto o nome empresarial é uma expressão da personalidade da empresa a marca é um patrimônio intelectual voltado para a identificação de produtos e serviços.

Finalmente, outro elemento que justifica a proteção do nome empresarial no universo da concorrência desleal está no fato de que, tal como as marcas, também possui a mesma tutela no artigo $5^{\circ}$ inciso XXIX da Constituição da República, com vistas ao interesse social e o desenvolvimento tecnológico e econômico do país, entretanto somente esta última possui a qualidade de direito de propriedade. Posicionamento legislativo críticado por Barcellos (2007, p. 61):

Outra questão conceitual interessante de se notar é que enquanto a CUP reconhece expressamente o nome comercial como direito de propriedade industrial, a LPI e o Código Civil de 2002 excluem esse direito da conceituação de "propriedade", de modo que é nítido que a Constituição Federal não eleva os direitos sobre o nome comercial (ou nome empresarial, conforme nova denominação atribuída pelo Código Civil de 2002) à categoria de propriedade, assim como a legislação ordinária também não o faz.

Realmente é importante destacar que o próprio artigo $2^{\circ}$ da Convenção da Organização Mundial da Propriedade Industrial reconhece como Propriedade Intelectual as firmas comerciais e as denominações comerciais ${ }^{10}$ (nome empresarial), entretanto, no Brasil essa

\footnotetext{
${ }^{10}$ Artigo $2^{\circ}$ da Convenção da Organização da Propriedade Intelectual: Para fins da presente Convenção entendese por: (...) VIII. Propriedade Intelectual os direitos relativos: às obras literárias, artísticas, científicas, às interpretações dos artistas, intérpretes e às execuções dos artistas executantes, aos fonogramas e às missões de radiodifusão, às invenções em todos os domínios da atividade humana, às descobertas científicas, aos desenhos e modelos industriais, às marcas industriais, comerciais e de serviço, bem como às firmas comerciais e
} 
proteção ganha um aspecto mais abrangente, como direito de personalidade e não como propriedade.

Atualmente o nome empresarial não é considerado pela doutrina e legislação brasileiras como um direito ou bem da propriedade industrial, tendo em vista as regras específicas sobre registro e princípios próprios, pelo qual destaca Ricardo Negrão (20112, p. 222):

Mas, no atual estágio de desenvolvimento doutrinário e legislativo, o nome não pode ser considerado direito de propriedade industrial, porque este se entende propriedade imaterial e se constitui coisa incorpórea, como ocorre com as marcas, patentes e desenhos industriais, que, após sua criação intelectual, ganham força de direito autônomo ao da personalidade de seu criador. O nome não dispõe dessa autonomia em razão de sua indissociabilidade da figura humana que o detém, como ocorre nas firmas, constituídas de nomes pessoais do empresário ou sócios da sociedade empresária, e, ainda, porque não pode ser alienado mesmo quando se tratar de sua forma denominativa, não vinculada a nomes pessoais (art. 1164 do Código Civil).

É inegável que a proteção que se confere tanto ao nome empresarial quanto às marcas está relacionada ao desenvolvimento econômico e tecnológico do país, pois assegura ao empresário a exploração de sua atividade distinguindo-se dos demais, preservando a liberdade de concorrência.

Converge então a proteção das marcas e do nome empresarial à proteção da liberdade de concorrência, havendo inclusive tratamento específico na lei 9.279/1976, pela qual a utilização indevida será considerada como concorrência ilícita.

Conclui-se, portanto, que existe uma grande diferença entre o nome empresarial e a marca no que diz respeito aos órgãos de registro e a natureza jurídica, entretanto, havendo colidência entre eles é necessário buscar elementos no direito da concorrência e da propriedade industrial para solucionar eventuais conflitos, preservando a identidade dos produtos e serviços oferecidos aos consumidores para evitar o desvio de clientela. Há, desse modo, uma relação íntima entre o direito da propriedade industrial e o direito da concorrência na preservação do nome empresarial como elemento do estabelecimento empresarial.

\section{TÍTULO DE ESTABELECIMENTO}

denominações comerciais, à proteção contra a concorrência desleal e todos os outros direitos inerentes à atividade intelectual nos domínios industrial, científico, literário e artístico. . Disponível em: http://www.fd.uc.pt/CI/CEE/OI/OMPI/Org_mundial_propriedada_intelectual.htm. Acesso em 25/04/2014. 
O título de estabelecimento, ou denominação de estabelecimento é sinal distintivo que visa diferenciar o empresário de seus concorrentes, representando importante papel no universo empresarial para "atrair clientela e diferenciar comerciantes e produtores." (CARVALHO, 2009, p. 601)

Pode ser conceituado como "o nome que o empresário dá à sua loja, à sua casa de comércio, para melhor divulgá-la e atrair clientela; é o que vai no frontispício do seu espaço de atuação." (GONÇALVES NETO, 2012, p. 665).

Possui função de relacionar a empresa ou seu titular ao negócio explorado, podendo ser formado pelo radical do nome empresarial (quando denominação) ou através de apelidos, alcunhas ou pseudônimo de um dos sócios do empresário.

Não se confunde com o nome empresarial, pois não está sujeito à registro. Da mesma forma diferencia-se das insígnias por se referir a indicação do estabelecimento como um todo.

Nesse sentido Pontes de Miranda entende por título de estabelecimento apenas o título que o estabelecimento empresarial recebe, destacado de forma visualmente perceptível à sua clientela, enquanto que a insígnia apresenta outros elementos, podendo ser composta por dizeres ou simbólica:

A insígnia pode ser em dizeres ou simbólica. Aquela consta de palavra, ou palavras, ou frase, sem ser título; essa, de desenho, emblema, figura ou símbolo. A insígnia em figura única é simbólica (e.g. a da Estátua da Liberdade, a do Corcovado). Se o estabelecimento é "Casa Carvalho" e abaixo há o emblema "Vender barato para vender muito", há o título de estabelecimento e a insígnia. ${ }^{11}$

Também não pode ser confundido com a marca ou o nome empresarial, seja pelo registro, pela natureza jurídica ou pela função que exercem.

A tutela evidenciada ao título de estabelecimento insere-se no âmbito da concorrência desleal, sendo inclusive considerado crime a sua utilização indevida com fins econômicos, tal como tipificado no art. 191 da Lei 9279/96, que pune a reprodução ou imitação de títulos de estabelecimento e insígnias que possam induzir a clientela em erro ou confusão ${ }^{12}$, bem como no artigo 195 inciso V da mesma lei, tipificando como crime de concorrência desleal quem usa, indevidamente, nome comercial, título de estabelecimento ou insígnia alheios.

\footnotetext{
${ }^{11}$ MIRANDA, P. op cit. p. 134.

12 Artigo 191 da Lei 9279/96 - Reproduzir ou imitar de modo que possa induzir em erro ou confusão, armas, brasões ou distintivos oficiais nacionais, estrangeiros ou internacionais, sem a necessária autorização, no todo ou em parte, em marca, título de estabelecimento, nome comercial, insígnia ou sinal de propaganda, ou usar essas reproduções ou imitações com fins econômicos. Pena - detenção de 1(um) a 3 (três) meses, ou multa.
} 
Tal como ocorre com os bens da Propriedade Industrial, o titular do título de estabelecimento e da insígnia possui o direito de impedir que outras pessoas os utilizem indevidamente, entretanto seguirá parâmetros para sua proteção de acordo com a natureza da atividade exercida, a anterioridade de sua utilização e sua influência geográfica.

Esse critério é indicado por Vivante (2007, p.149):

O juiz deve examinar caso por caso a fim de verificar se, pela semelhança da forma, pela uniformidade do comércio, pela vizinhança do local, uma denominação comercial pode prejudicar o proprietário de outra. Provando-se o perigo de uma concorrência prejudicial, o comerciante que primeiro a adotou, pode obrigar o outro a mudar a sua denominação comercial, porque, mesmo nesta matéria, a prioridade da posse dá direito à preferência. O proprietário de uma denominação comercial não tem necessidade de fazer o registro dela para gozar da tutela da lei, como se determinou quanto às marcas. O usurpador de má-fé será condenado a indenizá-lo dos danos, e terá de sofrer a apreensão da denominação comercial e multa.

Justifica-se a proteção do título de estabelecimento e das insígnias do empresário no universo concorrencial, pois também são elementos incorpóreos de distinção do empresário. Mesmo que esses dois elementos não possuam a mesma natureza jurídica das marcas, também podem ensejar em atos de confusão que prejudiquem a captação da clientela dos empresários de forma ilícita ou abusiva.

Seguindo esse entendimento o STJ, publicou decisão em 27/05/2015, no REsp 1237752 PR 2011/0034566-4, em que entendeu que o título de estabelecimento pode inclusive ser considerado um óbice ao registro de marca perante o INPI, quando seu elemento característico for conferido em âmbito nacional (o que implica em registro em todas as Juntas Comerciais), tal como se destaca no seguinte trecho da ementa:

A controvérsia relaciona-se à possibilidade de uso de vocábulo constante de marca mista registrada e a eventual configuração de concorrência desleal. 1. O elemento característico ou diferenciador de nome de empresa ou de título de estabelecimento será óbice ao registro da marca (art. 124, inciso V, da Lei no 9.279/1996 - LPI), quando a proteção ao nome empresarial for conferida em âmbito nacional. ${ }^{13}$

Nesse caso é importante que se destaque que o nome empresarial adotado pelo empresário deve ser complementar ao nome empresarial e mesmo não sendo agraciado com

\footnotetext{
${ }^{13}$ Disponível em: https://ww2.stj.jus.br/processo/revista/documento/mediado/?componente=ITA\&sequencial=1383622\&num_regi stro $=201100345664 \&$ data $=20150527 \&$ formato $=$ PDF
} 
registro próprio, ele deve ser declarado no contrato social do empresário, sendo esse instrumento devidamente registrado na Junta Comercial.

A proteção do título de estabelecimento como elemento de impedimento ao registro da marca somente poderá ser derivada dessa hipótese, respeitando-se inclusive o princípio da especialidade da marca.

Aceitar a tutela ampla do título de estabelecimento frente a marcas e nomes empresariais, seria criar um ambiente de intensa instabilidade jurídica aos empresários e aos consumidores, fato esse que implica reconhecer que os títulos de estabelecimento em regra possuem uma proteção jurídica em um nível inferior às marcas e nomes empresariais.

Ainda, pelo fato de não serem considerados um direito de propriedade, não podem ser objeto de comercialização individual, nem tampouco elemento de impedimento à exploração de outros empresários quando atuarem em ramos de negócios diferentes.

Veja-se que a Lei 9.279/96 ao declarar em seu art. 209 que o prejudicado pode pleitear perdas e danos pelos atos de concorrência desleal, vincula essa situação aos atos tendentes a prejudicar a reputação ou negócios alheios. Portanto, se aquele que se diz detentor de direitos sobre um determinado título de estabelecimento não explora a mesma atividade do seu concorrente, ou já deixou de explorar atividade econômica, não poderá pleitear a tutela jurídica concorrência a esse elemento do estabelecimento empresarial.

Portanto, os títulos de estabelecimento serão protegidos contra a concorrência desleal, apenas no âmbito de influência geográfica das atividades econômicas que se restringem, não se caracterizando como propriedade intelectual ou autoral de seus titulares.

\section{4 - MARCAS NÃO REGISTRADAS}

Hipótese pouco explorada pela doutrina está no fato de que eventuais nomes ou símbolos utilizados como títulos de estabelecimento ou insígnias podem também ser utilizados como elementos de diferenciação de produtos ou serviços, sendo, portanto, reconhecidos como marcas não registradas de produtos ou serviços, merecendo tutela na Lei 9279/96 como elementos de precedência para a requisição do competente registro.

O parágrafo primeiro do art. 129 dessa lei declara que toda pessoa de boa-fé que na data da prioridade do depósito usava no País, há pelo menos 6 (seis) meses, marca idêntica ou semelhante, para distinguir ou certificar produto ou serviço idêntico, semelhante ou afim, terá direito de precedência ao registro. 
Essa norma comprova a existência no Direito brasileiro de uma exceção ao princípio declaratório de que os bens da propriedade industrial somente receberiam tutela legal a partir do competente registro.

Reconhece-se a figura das marcas de fato ou marcas não registradas desde que estejam sendo utilizadas de modo prolongado, cujo mot vedette pode inclusive incluir elementos gramaticais ou figurativos das insígnias e dos títulos de estabelecimento. Assim, seus titulares tem a possibilidade real de obter o registro, "bastando, para tanto coligir provas perante o INPI de seu pré-uso (mínimo de seis meses) em relação às marcas iguais ou semelhantes de uso dos concorrentes". (SILVA, 2013, p. 165-166)

Entretanto, para que esses elementos de mot vedette ganhem a condição de marca de fato não basta a simples inclusão dos mesmos no contrato social da empresa, deve-se comprovar o efetivo uso nos produtos e serviços, tal como destaca José Roberto D’Affonseca Gusmão (1990, p 145):

Uma marca, seja ela de indústria, comércio ou serviço, destina-se a identificar produtos ou serviços de seu titular afim de os distinguir de produtos ou serviços idênticos ou similares provenientes de uma origem diferente.

O uso de uma marca constitui então no ato de aposição da marca no produto, ou em um bem material que acompanha um serviço, e permite identificá-lo no momento da venda ou da oferta de venda dos produtos ou serviços, ou qualquer ato de comercialização de produtos ou serviços.

As marcas de fato serão mais próximas portanto dos elementos gramaticais ou figurativos das insígnias do empresário, que tem a função de distinguir seus produtos e serviços de seus concorrentes, de modo que a falta do registro no INPI não implica em ausência de direitos.

Nesse sentido merece destaque o entendimento de Newton Silveira (2014, p. 15-16):

O sistema de registro de marcas e concessão de patentes de invenção e modelos é formalista e atende à necessidade de segurança e rapidez das relações comerciais. Nem sempre, porém, a falta de registro do título significa total ausência do direito.

(...)

No caso das marcas sem registro, não fica o utente totalmente desamparado. Socorre-se nas normas de repressão à concorrência desleal, nas quais incide todo ato tendente a estabelecer confusão entre produtos, mercadorias ou estabelecimentos.

A aproximação com as normas de repressão à concorrência desleal, entretanto, deve se pautar em consideração com a importância da atividade econômica e sua relação com os 
interesses da clientela, de modo que o direito de precedência ao também leve em consideração essa premissa.

É indispensável lembrar que essa relação com a clientela é segundo José Roberto D’Affonseca Gusmão a última condição para que uma marcar de fato tenha reconhecida a sua proteção legal (1990, p. 146):

A reunião da clientela é efetivamente o valor econômico e moral que se destina a ser protegida pelo direito. Em todas as decisões judiciais que têm reconhecido a proteção às marcas de uso, encontramos um terreno comum: o de evitar a confusão entre os produtos por parte da clientela (ou consumidor). O que se pretende evitar, em última análise, é que a clientela tome um produto como sendo um outro. No entanto, o objetivo da repressão da concorrência desleal não é o da defesa do consumidor, mas a proteção da boa-fé entre comerciantes e um mercado saudável e honesto. Assim, para que haja confusão ou um risco de confusão, se pressupõe a relação de uma clientela em torno da marca. Na verdade, não há confusão possível, mesmo que se está na presença de marcas idênticas, se uma destas marcas não é conhecida pelo cliente, e não motiva a preferência dele. Se fosse assim, faltaria o ator principal da confusão ou engano: a clientela.

É bom lembrar que o objetivo central da defesa da concorrência deve se traduzir "pelo balanço entre os potenciais benefícios e prejuízos de cada estrutura, mas sem perder a dimensão de que os interesses dos consumidores finais devem ser preservados". (REZENDE, 2013, p. $300)$.

Portanto, não se pode ter como absoluto o direito de precedência ao registro, tendo em vista a finalidade precípua da preservação da concorrência e dos preceitos de desenvolvimento econômico, previstos não só na legislação regulamentar da propriedade industrial, mas também no contexto constitucional. É fundamental aliá-lo ao reconhecimento do sinal distintivo como um marca não registrada.

Deve-se buscar ainda certa razoabilidade na aplicação da regra constante no parágrafo primeiro do artigo 129 da Lei 9279/96, pois que os títulos de estabelecimento e as insígnias possuem em sua natureza uma proteção regional e ao confrontarem-se com o registro de marca, estão apostas a uma nova realidade de tutela jurídica, cuja base territorial passa a ser nacional.

Corroborando tal entendimento, segue Denis Borges Barbosa (2014):

Entendemos que tal interpretação não é razoável. Não há outra hipótese de signos não registrados protegidos de forma incondicional - como se fosse o direito personalíssimo dos nomes civis (e nem mesmo exige-se a notoriedade imposta aos pseudônimos). Ou seja, mesmo os títulos obscuros, reservados, de um sapateiro conhecido mal 
e mal por meia dúzia de pessoas de um aldeia do Guaporé, estariam protegidos, se tal interpretação procedesse.

(...)

Em suma, a potencialização ofensiva deste valor concorrencial, sem qualquer contribuição correlativa ao interesse social, e ao desenvolvimento econômico e tecnológico do País, configura desbalanceamento írrito à Constituição. É valor obstativo de concorrência honesta e séria, e como potencial atentado à liberdade de iniciativa, merece leitura razoável.

Haverá, desse modo, uma inegável necessidade de proteção às marcas não registradas como elementos incorpóreos dos empresários, passíveis inclusive de proteção na esfera da concorrência desleal e como pressuposto de precedência para obtenção de registro, entretanto, essa tutela jurídica deve ser aplicada com o mínimo de razoabilidade pelos julgadores, a fim buscar em primeiro lugar o interesse daqueles a quem os produtos são endereçados e o desenvolvimento econômico que esta proteção pode gerar.

\section{CONCLUSÃO}

De todo o exposto, podemos concluir ao final que os elementos incorpóreos dos empresários representam uma importante ferramenta propulsora do desenvolvimento econômico empresarial, destacando o empresário de seus concorrentes.

Dentre esses elementos incorpóreos destacam-se o nome empresarial, o título de estabelecimento e a marca não registrada, que atualmente ganharam importância como mecanismos de divulgação do empresário.

A proteção legislativa específica desses elementos do estabelecimento empresarial acaba por se destacar no art. 195, V da Lei 9.279/96, bem como de forma genérica no art. 209 da mesma lei, inserindo-os no universo do direito da concorrência.

Nesse sentido foram esclarecidos os questionamentos formulados inicialmente, chegando a diversas conclusões.

Inicialmente quanto aos critérios de distinção utilizados pelo legislador quanto aos nomes empresariais e títulos de estabelecimento, percebeu-se eles estão sujeitos aos princípios da novidade e veracidade, diversos da especialidade e novidade relativa das marcas.

Quanto às marcas não registradas, foi destacado que nem todo símbolo em produtos ou serviços pode ser caracterizado como marca não registrada, devendo o mesmo atender aos 
mesmos critérios de registrabilidade das marcas, bem como ser reconhecidos pelos consumidores.

Foi demonstrado que mesmo sem registros específicos, tanto o título de estabelecimento quanto as marcas não registradas podem ser objeto de proteção jurídica, especialmente quanto premente o prejuízo do empresário de seus consumidores.

Por fim destaca-se que a presente pesquisa não teve a pretensão de esgotar o assunto, apenas contribuir para que as discussões sobre a tutela de nomes empresariais, títulos de estabelecimento e marcas não registradas possam continuar em debate a fim de que todos os elementos incorpóreos do estabelecimento empresarial possam servir de instrumento para o crescimento econômico e desenvolvimento social.

\section{BIBLIOGRAFIA}

ALMEIDA, Marcus Elidius Michelli de. Abuso do Direito e Concorrência Desleal. São Paulo: Quartier Latin, 2004.

BARBOSA, Denis Borges. Notas sobre títulos de estabelecimento. Disponível em http://www.denisbarbosa.addr.com/arquivos/200/propriedade/nota_titulos_estabelecimento.pd f. Acesso em 25 de julho de 2015.

. Tratado da Propriedade Intelectual. v. I, Rio de Janeiro: Lumen Juris, 2013.

BARCELLOS, Milton Lucídio Leão. Propriedade Industrial \& Constituição. Porto Alegre: Livraria do Advogado, 2007.

BUENO, Fabíola M. Spiandorello. A propriedade Industrial como fator de desenvolvimento econômico. Revista da ABPI. n. 80. Janeiro/fevereiro de 2006, p. 32-36.

CARVALHO DE MENDONÇA, José Xavier. Das Firmas ou razões comerciais. Atualizada por ZANTA JÚNIOR, Flávio Luiz. Sorocaba/SP: Editora Minelli, 2008.

CARVAlHO, Nuno Pires de. A estrutura dos sistemas de patentes e de marcas: passado, presente e futuro. Rio de Janeiro: Lumen Juris, 2009.

CASTELLI, Thais. Propriedade Intelectual. O princípio da Territorialidade. São Paulo: Quartier Latin, 2006.

CERQUEIRA, João da Gama. Tratado da Propriedade industrial. 2 ed. v.2. São Paulo: Revista dos Tribunais, 1982.

COELHO, Fábio Ulhoa. Curso de Direito Comercial. Direito de empresa. Empresa e estabelecimento. 16 ed. v. 1. São Paulo: Saraiva, 2012. 
COPETTI, Michele. Afinidade entre marcas: uma questão de Direito. Rio de Janeiro: Lumen Juris, 2010.

CORDEIRO, António Menezes. Direito Comercial. 3 ed. Coimbra: Almedina, 2012.

DINIZ, Maria Helena. Código Civil Anotado. 15 ed. São Paulo: Saraiva, 2010.

FORGIONI, P. A. A Evolução do Direito Comercial Brasileiro: da mercancia ao mercado.

São Paulo: Revista dos Tribunais, 2009

GONÇALVES NETO, Alfredo de Assis. Direito de Empresa. Comentários aos artigos 966 a 1195 do Código Civil. 4 ed. São Paulo: Revista dos Tribunais, 2012

GUSMÃO, José Roberto d' Affonseca. L'Acquisition du droit sur la marque au Brésil. Paris:, Éd. Litec, 1990.

MAMEDE, Gladston. Direito Empresarial Brasileiro. Empresa e Atuação empresarial. v. 1

São Paulo: Atlas, 2004

MIRANDA, Pontes de. Tratado de Direito Privado. Tomo XVII Direito das Coisas: propriedade mobiliária (bens incorpóreos). Propriedade Industrial (sinais distintivos). São Paulo: Revista dos Tribunais, 2013.

NEGRÃO, Ricardo. Manual de Direito Comercial \& de Empresa. Teoria Geral da Empresa e Direito Societário. 9 ed. v. 1 São Paulo: Saraiva, 2012.

REZENDE, Gustavo Madi e ALMEIDA, Sílvia Fagá de. Defesa do Consumidor e Disciplina Antitruste. in SCHAPIRO, Mario Gomes, CARVALHO, Vinícius Marques e CORDOVIL, Leonor (coord). Direito Econômico Concorrencial. São Paulo: Saraiva, 2013.

SILVA, Alberto Luís Camelier da. Concorrência Desleal. Atos de confusão. São Paulo: Saraiva, 2013.

SILVEIRA, Newton. Propriedade Intelectual. Propriedade Industrial, Direito de Autor, Software, Cultivares, nome empresarial, abuso de patentes. 5ed. Barueri/SP: Manole, 2014. SIMÃO FILHO, Adalberto e LUCCA, Newton de. Direito Empresarial Contemporâneo. São Paulo: Juarez de Oliveira, 2000

TOMAZETTE, Marlon. Curso de Direito Empresarial. Teoria Geral e Direito Societário, São Paulo: Atlas, 2008.

VIVANTE, Cesare. Instituições do direito comercial. 2 ed. Sorocaba-SP: Editora Minelli, 2007. 